\title{
RABBIT GROWTH PERFOMANCE AS AFFECTED BY DIETARY LEVELS OF DATE WASTE MEAL
}

\author{
H.A. Abo-Eid; M.S. Abousekken and I.A.M. El-Folly
}

Sustainable Development Department, Environmental Studies and Research Institute (ESRI), University of Sadat City, Egypt.

\author{
(Received 1/5/2016, Accepted 13/6/2016)
}

\section{SUMMARY}

\begin{abstract}
$\mathrm{T}$ his study was performed during the period from April to June 2014 (90 days), at Maryout Research Station belongs to Desert Research Center (DRC), Ministry of Agriculture and Land Reclamation, in cooporation with Environmental Sustainable Development Department, Environmental Studies \& Research Institute (ESRI), University of Sadat City, Menofiea Governorate, Egypt. It was conducted to investigate the effect of incorporating different levels of dietary date waste meal (DWM) at 0.0, 10, 20, 30 and $40 \%$ of the diet with or without adding zylam (Z) on feed intake and body weight gain of New White Zealand (NZW) rabbits. Sixty growing NZW rabbits (30 males and 30 females) aged 8 weeks with anaverage weight $1.530 \pm 0.36 \mathrm{~kg}$ for both two sexes were used in this study. Both sexes were divided into five equal groups (6 in each) according to the level of DWM replacement (0.0 C, $10 \mathrm{~T}_{1}, 20 \mathrm{~T}_{2}, 30 \mathrm{~T}_{3}$ and $\left.40 \mathrm{~T}_{4} \%\right)$. Each group was divided into two groups ( 3 in each) according to adding enzyme (with or without). Group $\mathrm{T}_{2} \mathrm{Z}$ significantly $(p<0.05)$ recorded the best digestion coefficient values $(74.66 ; 74.91 ; 87.64 ; 52.8 ; 83.18$ and $79.46 \%$ for DM; OM, CP, CF; EE and NFE, respectively) comparing with control and other experimental diets, while at $40 \%$ DWM with zylam ( $\mathrm{T}_{4} \mathrm{Z}$ group) was the worst one. Digestibility of DM, OM, CP, EE and NFE significantly $(\mathrm{p}<0.05)$ decreased by increasing dietary DWM levels. Group fed $20 \%$ dietary DWM with zylam $\left(\mathrm{T}_{2} \mathrm{Z}\right)$ significantly $(\mathrm{p}<0.05)$ recorded a best digestible nutrients and nutritive values [TDN $(66.88 \%)$ and NB $(2.7 \%)$ ] compared with control and other experimental groups. Inclusion of date waste meal (DWM) at $10 \%$ recorded significantly $(\mathrm{p}<0.05)$ an increase in final live body weight $(\mathrm{LBW})$ compared with $30 \%$ and $40 \%$. Insignificant ( $>0.05$ ) differences were detected between treated and control group for feed conversion ratio (FCR). Insignificant differences were observed for different dietary levels of DWM on cholesterol, triglycerides, ALT, AST.and not negatively affected liver activity or rabbit's health. Conclusively, it could be concluded that diets containing up to $20 \%$ of date waste meal (DWM) and supplemented with $1 \mathrm{~g}$ zylam during growing period could be used safely in rabbit diets during growing period.
\end{abstract}

Keywords: Date palm, digestibility, growing rabbits, performance and blood parameters

\section{INTRODUCTION}

Rabbits have high efficiency in the meat production compared to other farm animals. Rabbits provide an excellent source of protein for human consumption and may play an important role in solving the meat shortage problem in developing countries (Abdel-Azeem et al., 2007). According to Jiao et al. (2014), there is a moderate positive genetic correlation between growth and feed intake as well as average daily gain and feed conversion ratio. It is well known that large number of factors can affect the dry matter intake of animals. These include breed, age, physiological status, palatability of the feed and others. Dates, the fruits of the date palm tree (phoenix dactylifera) are major staple food in arid areas of North Africa and Middle East, as the date crop plays role in the economy and social life in these regions (FAO, 2007). Whole dates contain approximately $15 \%$ pits, and their value of energy is significantly lower than that of pitted dates and date pulp (Jassim and Naji, 2010). Exogenous enzymes bind temporally to one or more of the reactants which they catalyze and so lower the amount of energy needed thereby, speeding up the reaction (El-Deek et al., 2008 and Ibrahim et al., 2010). Ogunsipe (2014) found that enzyme supplemented diets of cross-breed rabbits improved nutrients digestibility and utilization as evidenced in the feed conversion ratio and weight gain of the experimental rabbits. Although the use of date waste has been mainly in ruminant feeds, many studies have been conducted on feeding broiler on date waste meal (DWM) and led to an improvement in broiler performance (Al-Harthi et al., 2009; El-Sheikh et al. 2013 and Fadare, 2015). The current study aimed to investigate the effects of incoporating DWM at different 
levels $(0.0,10,20,30$ and $40 \%)$ with or without Zylam $(0.1 \%)$ in rabbit's diets on growth performance, nutrients digestibility, blood serum parameters and economical efficiency under desert environmental conditions.

\section{MATERIALS AND METHODS}

The present study was carried out from April to June 2014 at Maryout Research Station (Poultry Production Sector), which belongs to Desert Research Center, Ministry of Agriculture and Land Reclamation, Egypt.

\section{Animals, housing and experimental design}

The study involved sixty growing White New Zealand (NZW) rabbits (30 males and 30 females), aged 8 weeks with initial mean weight $1.530 \pm 0.36 \mathrm{~kg}$ for both two sexes. The animals divided on the basis of their sex into two main equally groups. Each gender was divided into five equal groups $(0.0,10$, 20,30 and $40 \%$ of date waste meal) according to the replacement level of date waste meal (DWM) in diet then each group was allotted into two sub-groups (3 replicates of each) according to adding Zylam to diets (with or without). The study lasted three months period (from April till June, 2014), All animals were individually housed in galvanized wire cages $(50 \times 55 \times 39 \mathrm{~cm})$ provided with a feeder and automatic nipple drinker, and were kept under the same managerial conditions.

Five formulated diets of $17 \%$ crude protein contained $0.0,10,20,30$ and $40 \%$ of date waste meal in diet with or without Zylam supplementation $(0.1 \%)$ were investigated on growth performance, some blood biochemical parameters and nutrients digestibility of NZW rabbits as follows (Table 1):

Table (1). Experimental design of the study.

\begin{tabular}{|c|c|}
\hline \multicolumn{2}{|c|}{ Experimental groups in both males (30) and females (30) } \\
\hline 3 replications in each & 3 replications in each \\
\hline $0.0 \%$ DWM without Zylam $\quad(\mathrm{CC})$ & $0.0 \%$ DWM with Zylam $\quad(\mathrm{CZ})$ \\
\hline 10\% DWM without Zylam $\quad\left(\mathrm{T}_{1} \mathrm{C}\right)$ & $10 \%$ DWM with Zylam \\
\hline $20 \%$, DWM without Zylam $\quad\left(\mathrm{T}_{2} \mathrm{C}\right)$ & $20 \%$ DWM with Zylam \\
\hline 30\% DWM without Zylam $\quad\left(\mathrm{T}_{3} \mathrm{C}\right)$ & 30\% DWM with Zylam \\
\hline 40\% DWM without Zylam & 40\% DWM with Zylam \\
\hline
\end{tabular}

DWM = date waste meal, Zylam was added at level of $0.1 \%$.

\section{Date waste male $(\mathrm{DWM})$ preparation}

Low quality of date palm had been used as a source of energy, protein and fiber at 0.0, 10, 20, 30 and $40 \%$ of the diet. Date palm was obtained through a dealer in Siwa Oasis that collecting different varieties of date palm, which classified as a by- product feedstuff according to palatability (less for human). The whole date palm was sun dried to reduce moisture content, and then ground by electrical mill with stones. Water content of dry date flesh and date pits was determined according to the methods of Official Analytical Chemists (AOAC, 2000). Ash and minerals contents in powdered flesh or pit were determined using muffle furnace at about $530^{\circ} \mathrm{C}$ for 5 hours. Ashes were expressed as percent of dry weight.

\section{Experimental diets}

Table (2) shows the composition of experimental diets which were used for feeding. Date waste male (DWM) was incorporated in diets at 0.0, 10, 20, 30 and 40\% replacing clover hay, wheat bran and yellow corn. The diets were kept iso-nitrogeneous and isocaloric in the experiment. Dates were dried in an automatic oven at $\left(60^{\circ} \mathrm{C}\right)$ for 24 hours, after that dates were ready to be grinded with crushing.

It is well known that ,enzymes are added to animal ration with the goal of increasing its digestibility, removing anti-nutritional factors, improving nutrient availability as well for environmental issues (AlHarthi, 2006 and El-Deek et al., 2003), therefore Zylam that contain Amylase 160.000, Xylanase 1.500.00, Cellulase 1.000.000, B. Glucanase $100.000 \mathrm{U} / \mathrm{g}$ are added to the above diets. 
Egyptian J. Nutrition and Feeds (2016)

Table (2). Formulation and chemical analysis of the experimental diets.

\begin{tabular}{|c|c|c|c|c|c|}
\hline Ingredients & $\begin{array}{c}\text { Control }(\mathrm{CC}) \\
0.0 \% \mathrm{DWM}\end{array}$ & $\begin{array}{c}\mathrm{T}_{1} \\
10 \% \mathrm{DWM}\end{array}$ & $\begin{array}{c}\mathrm{T}_{2} \\
20 \% \text { DWM }\end{array}$ & $\begin{array}{c}\mathrm{T}_{3} \\
30 \% \text { DWM }\end{array}$ & $\begin{array}{c}\mathrm{T}_{4} \\
40 \% \text { DWM }\end{array}$ \\
\hline Clover Hay & 25.00 & 25.00 & 30.00 & 22.00 & 07.50 \\
\hline Wheat bran & 26.00 & 30.00 & 25.50 & 04.00 & - \\
\hline Date Waste meal & - & 10.00 & 20.00 & 30.00 & 40.00 \\
\hline Barley grains ,Ground & 20.00 & 14.50 & 01.50 & - & - \\
\hline Soybean meal (44\% CP) & 13.50 & 14.50 & 16.50 & 25.00 & 28.00 \\
\hline Yellow corn, ground & 10.00 & - & - & - & - \\
\hline Wheat straw & 01.50 & 02.00 & 02.50 & - & - \\
\hline Clover Straw & - & - & - & 15.00 & 20.50 \\
\hline Dl-Methionine & 00.35 & 00.35 & 00.35 & 00.35 & 00.35 \\
\hline Premix $*$ & 00.50 & 00.50 & 00.50 & 00.50 & 00.50 \\
\hline $\mathrm{NaCl}$ & 00.35 & 00.35 & 00.35 & 00.35 & 00.35 \\
\hline Di calcium phosphate & 01.90 & 01.90 & 01.90 & 01.90 & 01.90 \\
\hline $\mathrm{CaCO} 3$ & 00.90 & 00.90 & 00.90 & 00.90 & 00.90 \\
\hline Zylam** & $(-)(+)$ & $(-)(+)$ & $(-)(+)$ & $(-)(+)$ & $(-)(+)$ \\
\hline Total $(\mathrm{kg})$ & 100 & 100 & 100 & 100 & 100 \\
\hline \multicolumn{6}{|l|}{ Calculated values $* * *$} \\
\hline Crude protein $\%$ & 17.24 & 17.26 & 17.12 & 17.39 & 16.51 \\
\hline $\mathrm{ME}, \mathrm{kcal} / \mathrm{kg}$ diet & 2520 & 2523 & 2538 & 2516 & 2533 \\
\hline Crude fiber $\%$ & 12.00 & 13.14 & 14.25 & 15.67 & 14.31 \\
\hline Ether extract \% & 2.59 & 02.45 & 02.33 & 01.65 & 01.43 \\
\hline Calcium \% & 01.10 & 01.21 & 01.32 & 01.43 & 01.45 \\
\hline Available phosphorus & 00.41 & 00.46 & 00.52 & 00.58 & 00.61 \\
\hline Lysine \% & 00.81 & 00.84 & 00.87 & 00.95 & 00.95 \\
\hline Methionine & 00.60 & 00.59 & 00.59 & 00.58 & 00.56 \\
\hline \multicolumn{6}{|l|}{ Determined values : } \\
\hline Crude protein $\%$ & 17.43 & 16.98 & 17.33 & 17.36 & 16.75 \\
\hline Crude fiber $\%$ & 12.74 & 12.53 & 13.54 & 14.01 & 13.82 \\
\hline Ether extract \% & 03.11 & 02.55 & 02.86 & 03.01 & 02.76 \\
\hline $\mathrm{DE},(\text { Mcal } / \mathrm{kg})^{*} \operatorname{diet}$ & 02.37 & 02.54 & 02.51 & 02.49 & 02.50 \\
\hline Cost $/ \mathrm{kg}$ of diet in L.E. $* * * *$ & 02.73 & 02.38 & 02.31 & 02.44 & 02.45 \\
\hline
\end{tabular}

${ }^{*}$ The premix (Vit. \& Min.) was added at a rate of $3 \mathrm{~kg}$ per ton of diet and supplied the following per $\mathrm{kg}$ of diet (as $\mathrm{mg}$ or I.U. per kg of diet): Vit. A 12000 I.U., Vit. D3 2000 I.U., Vit. E 40 mg, Vit. K3 4 mg, Vit. B1 3 mg, Vit. B2 6 mg, Vit. B6 $4 \mathrm{mg}$, Vit. B12 $0.03 \mathrm{mg}$, Niacin $30 \mathrm{mg}$, Biotin $0.08 \mathrm{mg}$, Pantothenic acid $12 \mathrm{mg}$, Folic acid $1.5 \mathrm{mg}$, Choline chloride $700 \mathrm{mg}$, Mn $80 \mathrm{mg}$, Cu $10 \mathrm{mg}$, Se $0.2 \mathrm{mg}, \mathrm{I} 40 \mathrm{mg}$, Fe $40 \mathrm{mg}$, Zn $70 \mathrm{mg}$ and Co $0.25 \mathrm{mg}$.

** Each Experimental diet devided into 2 patches: the frist Patch not-supplemented with Zylam (-) and the other supplemented with $0.1 \%$ Zylam (+)

${ }^{* * *}$ According to Feed Composition Tables for animal \& poultry feedstuffs used in Egypt (2001) and NRC (1994). ${ }^{* * * *}$ According to market prices of the year 2014.

Individual body weight was taken weekly to the nearest $\pm 2.0 \mathrm{~g}$ by digital weighing scale (Mettler Toledo, Top Pan Sensitive Balance, J. Liang Int. Ltd. U.K.). The measurements were taken while the animals were held in a standing position.

Individual body weight gain (BWG) for each rabbit was calculated at 2, 4, 6, 8, 10 and 12 weeks of experimental period by subtracting the initial LBW of a certain period from the final LBW of the same period, as follows:- $\mathrm{BWG}=\mathrm{W}_{2}-\mathrm{W}_{1}$

Where: $\mathrm{W}_{1}=\mathrm{LBW}$ at the onset of a certain period.

$\mathrm{W}_{2}=\mathrm{LBW}$ at the end of the same period.

Feed intake (FI) for each replicate under each treatment was weekly calculated, on a group basis, by subtracting the residual feed from the offered one. Average daily feed intake per rabbit was then calculated by using the following equations: 
$\mathrm{FI} /$ rabbit/day $=$

FI / replicate/week

No. of rabbits consumed feed daily during the week period

The feed conversion ration (FCR) values (using the weight of mortality to correct FI data), weekly and allover the experimental period were calculated for each replicate under each treatment by using the following formula:

$$
\text { FCR }=\frac{\text { FI }(\mathrm{g}) / \text { replicate during a certain period }}{\text { LBWG }(\mathrm{g}) / \text { replicate during the same period }}
$$

The performance index (PI), weekly and for the whole experimental period, was calculated for each replicate under each treatment according the equation reported by North (1981) as follows:

$$
\mathbf{P I}=\frac{L B W(k g)}{F C R} \quad \times \mathbf{1 0 0}
$$

Table (3): Proximate Analysis (DM basis \%), Fiber fractions, g/kg DM and energy value of DWM.

\begin{tabular}{lc}
\hline Component & \% DM basis \\
\hline Dry matter (DM) & 89.30 \\
Organic matter (OM) & 96.31 \\
Crude protein (CP) & 05.85 \\
Ether extract (EE) & 01.96 \\
Crud fiber(CF) & 07.58 \\
Nitrogen free extract (NFE) & 80.92 \\
Ash & 03.69 \\
Calcium $(\mathrm{Ca})$, & 00.91 \\
Total Phosphorus (p), & 00.64 \\
Methionine, & 00.92 \\
Lysine , & 00.31 \\
Fiber fractions , g/kg DM:* & \\
NDF & 33.90 \\
ADF & 80.12 \\
ADL & 93.71 \\
Hemi-cellulose & 46.22 \\
Cellulose & 13.59 \\
DE (Mcal/kg)** & 02.70 \\
\hline$* N D F:$ neutral detergent fiber; ADF: Acid detergent fiber; ADL: Acid detergent lignin. \\
$* * D E($ Mcal/kg) = 4.36 - 0.049 x NDF, NDF\% = 28.924 +0.657 (CF\%) according to Cheeke et al. (1982).
\end{tabular}

\section{Chemical analyses}

Proximate analysis of the diets, feedstuffs and feces were analyzed according to AOAC (2000) methods. All chemical analyses for feedstuffs and dried feces samples were carried out at Central Laboratory for Feed and Food, Agricultural Research Centre, Ministry of Agriculture. Nitrogen free extract (NFE) on DM basis was calculated by the difference $[\mathrm{NFE}=100-(\mathrm{CP} \%+\mathrm{EE} \%+\mathrm{Ash} \%+\mathrm{CF}$ $\%)]$.

\section{Plasma biochemical analysis}

Total plasma protein $(\mathrm{g} / \mathrm{dl})$ was determined colorimetrically using Buriet method as described by Cannon et al. (1974).

Plasma albumin content $(\mathrm{g} / \mathrm{dl})$ was determined by colorimetric method using bromocresol green at $\mathrm{pH}$ 4.2. The optical density of the standard or the samples was measured at wave length $628 \mathrm{~nm}$ according to the method described by Daumas (1971). The concentration of plasma globulin (g/dl) was 
estimated by subtracting plasma albumin from plasma total proteins. Albumin/Globulin ratio (A/G ratio) was calculated as follows:

$$
\mathrm{A} / \mathrm{G} \text { ratio }=\{\text { Plasma albumin }(\mathrm{g} / \mathrm{dl}) / \text { Plasma globulins }(\mathrm{g} / \mathrm{dl})\} \times 100 .
$$

Plasma total cholesterol $(\mathrm{CHO})$ concentration $(\mathrm{mg} / \mathrm{dl})$ was determined according to the method of Watson (1960). Plasma triglycerides (Tri) concentration (mg/dl) was determined according to Trinder (1969).

In order to evaluate the liver function under the effects of the physiological and nutritional factors, the plasma enzymes concentrations $(\mathrm{u} / \mathrm{l})$ of both alanine amino transferase (ALT) and aspartate aminotransferase (AST) were assayed according to Reitman and Frankel (1957).

\section{Statistical analysis}

The statistical analysis for the feeding trials were performed by using the general linear model (GLM) procedures according to SAS (2006) and significant mean differences between treatment means were distinguished by Duncan's Multiple Range Test (Duncan, 1955). All statements of significance were based on $\mathrm{P} \leq 0.05$. The statistical model used in this experiment was as following:

$\mathrm{Y}_{\mathrm{ijkl}}=\mu+\mathrm{t}_{\mathrm{i}}+\mathrm{s}_{\mathrm{j}}+\mathrm{z}_{\mathrm{k}}+(\mathrm{t} * \mathrm{~s})_{\mathrm{ij}}+(\mathrm{t} * \mathrm{z})_{\mathrm{ik}}+(\mathrm{s} * \mathrm{z})_{\mathrm{jk}}+(\mathrm{t} * \mathrm{~s} * \mathrm{z})_{\mathrm{ijk}}+\mathrm{e}_{\mathrm{ijkl}} \cdot$

Where,

$\mathrm{Y}_{\mathrm{ijkl}} \quad$ is the dependent variable of the $\mathrm{n}^{\text {th }}$ record in the $\mathrm{i}^{\text {th }}$ Date waste meal, $\mathrm{j}^{\text {th }}$ sex, $\mathrm{k}^{\text {th }}$ Enzym;

$\mu \quad$ is the overall mean,

$t_{i} \quad$ is the effect of the $i^{\text {th }}$ Date waste meal, $\mathrm{I}($ level $)=1(10 \%), 2(20 \%), 3(30 \%)$ and $4(40 \%)$;

$\mathrm{s}_{\mathrm{j}} \quad$ is the effect of the $\mathrm{j}^{\text {th }}$ sex, $\mathrm{j}=1$ (male) to 2 (female);

$z_{k} \quad$ is the effect of the $k^{\text {th }}$ enzyme, $k=1$ (with enzym) to 2 (without enzym);

$\left(t^{*} s\right)_{i j} \quad$ is the effect of interaction between the $i^{\text {th }}$ Date waste meal level and the $j^{\text {th }} s e x$;

$\left(\mathrm{t}^{*} \mathrm{z}\right)_{\mathrm{ik}} \quad$ is the effect of interaction between the $\mathrm{i}^{\text {th }}$ Date waste meal level and the $\mathrm{k}^{\text {th }}$ enzyme;

$\left(s^{*} \mathrm{z}\right)_{\mathrm{jk}} \quad$ is the effect of interaction between the $\mathrm{j}^{\text {th }}$ sex and the $\mathrm{k}^{\text {th }}$ enzyme

$\left(t^{*} \mathrm{~s}^{*} \mathrm{z}\right)_{\mathrm{ijk}}$ is the effect of interaction between the $\mathrm{i}^{\text {th }}$ Date waste meal level, the $\mathrm{j}^{\text {th }}$ sex and the $\mathrm{k}^{\text {th }}$ enzyme;

$\mathrm{e}_{\mathrm{ijkl}} \quad$ is the effect of experimental random error, associated with each observation assumed to be normally and independently distributed with 0 mean and variance $\sigma_{\mathrm{e}}^{2} \mathrm{I}$.

\section{RESULTS AND DISCUSSION}

\section{Chemical analysis of date waste meal (DWM)}

Chemical analysis (on DM basis \%) of date waste meal (DWM) are presented in Table (3). Analyzed data showed that, it had a considerable amount of crude protein $(5.85 \%)$ with low level of ether extract (1.96\%). Also, it contained high level of crude fiber (7.58\%) which consists mainly of NDF $(33.90 \mathrm{~g} / \mathrm{kg})$; $\operatorname{ADF}(80.12 \mathrm{~g} / \mathrm{kg}) ; \operatorname{ADL}(93.71 \mathrm{~g} / \mathrm{kg})$; Cellulose $(82.46 \mathrm{~g} / \mathrm{kg})$; and hemi-cellulose $(5.42 \mathrm{~g} / \mathrm{kg}))$ and nitrogen free extract $(80.94 \%)$. This means that DWM might be considered as a promising source of energy and dietary fiber in poultry and rabbits diets. Similar results were reported earlier by (Al-Homidan, 2003 and Al-Harthi et al., 2009) and recently by El-Sheikh et al. (2013) and (2015) who reported that date are considered as a good energy source for poultry. However, the remarkable high contents of crude fiber $(7.58 \%)$ and its fractions might be considered as a limiting factor in formulating poultry diets (Sawaya et al., 1984) especially regarding the availability of amino acids (Babatunde et al., 1975).

It was observed that chemical composition varies between cultivars of the same species and genotype. Furthermore, the agronomic cultivation conditions such as factors of environment prior to harvest and storage conditions after harvest can influence on chemical composition of DWM according to El-Sheikh et al. (2013 and 2015), who reported that chemical composition of DWM might vary according to the date type, maturity stage of the fruit and conditions relating to the circumstances of the experiment. 


\section{Abo-Eid et al.}

\section{Chemical composition of tested diets}

Chemical analyses of experimental diets (as fed) are shown in Table (4).

Table (4). Chemical composition (Proximate analysis) of experimental rations (as fed).

\begin{tabular}{|c|c|c|c|c|c|c|c|c|c|}
\hline Item & $\begin{array}{c}\mathrm{DM} \\
\%\end{array}$ & $\begin{array}{c}\text { Moisture } \\
\%\end{array}$ & $\begin{array}{c}\mathrm{OM} \\
\%\end{array}$ & $\begin{array}{l}\mathrm{CP} \\
\%\end{array}$ & $\begin{array}{l}\mathrm{CF} \\
\%\end{array}$ & $\begin{array}{l}\mathrm{EE} \\
\%\end{array}$ & $\begin{array}{c}\text { NFE } \\
\%\end{array}$ & $\begin{array}{c}\text { Ash } \\
\%\end{array}$ & $\begin{array}{c}\mathrm{DE} \\
(\mathrm{Mcal} / \mathrm{kg})^{*}\end{array}$ \\
\hline Ration1 & 92.23 & 7.77 & 79.37 & 17.43 & 12.74 & 3.11 & 46.09 & 12.86 & 2.37 \\
\hline Ration2 & 89.85 & 10.15 & 78.10 & 16.98 & 12.53 & 2.55 & 46.04 & 11.75 & 2.54 \\
\hline Ration3 & 90.86 & 9.14 & 76.83 & 17.33 & 13.54 & 2.86 & 43.10 & 14.03 & 2.51 \\
\hline Ration4 & 91.97 & 8.03 & 77.84 & 17.36 & 14.01 & 3.01 & 43.46 & 14.13 & 2.49 \\
\hline Ration5 & 92.86 & 7.14 & 78.93 & 16.75 & 13.82 & 2.76 & 45.60 & 13.93 & 2.50 \\
\hline
\end{tabular}

\section{Nutrient digestion coefficients and feeding value of experimental diets}

Results illustrated in Table (5) revealed that the digestion coefficients of dietary DM were significantly $(\mathrm{p}<0.05)$ higher among groups fed 0.0 (control); 10 and 20\% DWM diets than those contain 30 or $40 \%$ dietary DWM and also, showed the adverse effect on digestion coefficient of nutrients by increasing DWM levels, which may be attributed to the high crude fiber content in DWM, which in consequence may reduce digestibility and availability of nutrients. The same trend was observed with $\mathrm{CP}$ and CF digestion coefficients and TDN. Data indicated that group fed $20 \%$ dietary DWM with zylam $\left(\mathrm{T}_{2} \mathrm{Z}\right)$ significantly $(\mathrm{p}<0.05)$ recorded the best digestibility values $(74.66,74.91,87.64,52.8,83.18,79.46$ and $66.88 \%$ for DM, OM, CP, CF, EE, NFE and TDN, respectively) comparing with control and other experimental diets, while the level of $40 \%$ DWM with zylam $\left(\mathrm{T}_{4} \mathrm{Z}\right)$ group was the worst one. With the same trend, results detected that dietary enzyme supplementation significantly $(\mathrm{p}<0.05)$ improved digestibility coefficients values for dietary nutrients. Rabbits fed $1 \mathrm{~g}$ enzym (Zylam) showed higher $(\mathrm{P}<0.05)$ digestion coefficients of DM, OM, CP, CF, EE and NFE. The same trend was observed with TDN. These findings are in agreement with those obtained by El-Sheikh et al (2015) who noted that all digestion coefficients and nutritive values improved by using enzyme treatments. Also, These findings are agree with those reported by (Najib et al., 1995) who found that hens fed the control group recorded significantly the best digestion coefficient of OM, CP, EE and NFE compared to 10, 20, 30 and 40\% ADM. Taha et al. (2013) found that protein digestibility was significantly decreased when date waste was fed at $20 \%$ compared to the other levels of date waste.

\section{Nitrogen balance}

Data of nitrogen intake (NI), fecal nitrogen (FN), urinary nitrogen (UN), nitrogen retention (NR) and biological value (BV) are presented Table (6). Results showed that group fed $20 \%$ DWM with zylam $\left(\mathrm{T}_{2} \mathrm{Z}\right)$ recorded significantly $(\mathrm{p}<0.05)$ higher values of $\mathrm{NI}, \mathrm{NR}$ and $\mathrm{BV}$ values being $3.05 \mathrm{~g}, 2.70 \mathrm{~g}$ and $88.35 \%$, respectively) where the group fed $30 \%$ dietary DWM without zylam $\left(\mathrm{T}_{3} \mathrm{C}\right)$ significantly $(\mathrm{p}<0.05)$ recorded the worst BV (49.6\%) (Table 6). These results indicated that increasing the availability of nutrients causing an improvement in digestion coefficients and nutritive values. Some additives and treatments may counteract some of these problems, for example enzyme mixture could support the endogenous enzymes of the poultry (amylase and protease), break down of components in cell wall, which can't be broken down into absorbable nutrients by endogenous enzymes, lowering the gastrointestinal viscosity in digestive tract, reducing nutrient entrapment and releasing other nutrients like minerals (El-Sheikh et al., 2015).

\section{Growth performance}

\section{Live Body weight (FBW) and body weight gain (BWG)}

Data in Table (7) showed that, date waste meal (DWM) inclusion at $10 \%$ indicated a significant $(\mathrm{p}<0.05)$ increase in final live body weight (FLBW) compared with $30 \%$ and $40 \%$, while it presented insignificant $(\mathrm{p}>0.05)$ increase compared to control group and $20 \%$. 
Egyptian J. Nutrition and Feeds (2016)

Tables 5-6 
Table (7). Means \pm SE of final live body weight (FLBW), total gain (TG), total feed intake (TFI), feed conversion (FCR) and performance index (PI) of growing rabbit as affected by different levels of dietary date waste meal (DWM) with or without enzyme.

\begin{tabular}{cccccc}
\hline Item & FLBW & TG & TFI & FCR & PI \\
\hline DWM Level effect & & & & & \\
Control & $2.66^{\mathrm{a}} \pm 0.11$ & $1.07 \pm 0.13$ & $7.32^{\mathrm{ab}} \pm 0.11$ & $7.48^{\mathrm{b}} \pm 1.06$ & $39.45^{\mathrm{ab}} \pm 5.13$ \\
$10 \%$ & $2.85^{\mathrm{a}} \pm 0.11$ & $1.23 \pm 0.13$ & $7.48^{\mathrm{a}} \pm 0.11$ & $6.76^{\mathrm{b}} \pm 1.06$ & $47.59^{\mathrm{a}} \pm 5.13$ \\
$20 \%$ & $2.55^{\mathrm{ab}} \pm 0.11$ & $0.99 \pm 0.13$ & $7.48^{\mathrm{a}} \pm 0.11$ & $8.40^{\mathrm{ab}} \pm 1.06$ & $34.47^{\mathrm{ab}} \pm 5.13$ \\
$30 \%$ & $2.23^{\mathrm{bc}} \pm 0.11$ & $0.84 \pm 0.13$ & $7.51^{\mathrm{a}} \pm 0.11$ & $10.72^{\mathrm{a}} \pm 1.12$ & $25.40^{\mathrm{b}} \pm 5.45$ \\
$40 \%$ & $2.07^{\mathrm{c}} \pm 0.11$ & $0.92 \pm 0.13$ & $7.06^{\mathrm{b}} \pm 0.11$ & $8.11^{\mathrm{a}} \pm 1.19$ & $29.53^{\mathrm{b}} \pm 5.74$ \\
Sg. & $*$ & $\mathrm{NS}$ & $*$ & $*$ & $*$ \\
Sex Effect & & & & & \\
M & $2.49 \pm 0.07$ & $1.01 \pm 0.08$ & $7.30 \pm 0.07$ & $8.17 \pm 0.69$ & $36.46 \pm 3.33$ \\
F & $2.46 \pm 0.07$ & $1.01 \pm 0.08$ & $7.44 \pm 0.07$ & $8.42 \pm 0.70$ & $34.11 \pm 3.41$ \\
Sg. & $\mathrm{NS}$ & $\mathrm{NS}$ & $\mathrm{NS}$ & $\mathrm{NS}$ & $\mathrm{NS}$ \\
Enzyme Effect: & & & & & \\
With: & $2.55 \pm 0.07$ & $1.09 \pm 0.08$ & $7.40 \pm 0.07$ & $8.39 \pm 0.67$ & $38.82 \pm 3.25$ \\
Without: & $2.40 \pm 0.07$ & $0.93 \pm 0.08$ & $7.33 \pm 0.07$ & $8.19 \pm 0.72$ & $31.75 \pm 3.48$ \\
Sg. & $\mathrm{NS}$ & $\mathrm{NS}$ & $\mathrm{NS}$ & $\mathrm{NS}$ & $\mathrm{NS}$ \\
\hline
\end{tabular}

$a, b, . . e t c .:$ Means in the same column with different letters, differ significantly $(P<0.05) . \quad N S=$ not significant.

These results are in agreement with Ali et al. (1999) who found that powdered date pits addition at a concentration of $14 \%$ significantly increased the body weight of rats. On the other hand, El-Sheikh et al. (2013) found that final body weight; body weight change and feed consumption were not affected significantly by Azzawi date meal (ADM) as a non-conventional feedstuff in local laying hen diets at 10, 20,30 , and $40 \%$ inclusion of the diet.

The findings in Table (7) shows that date waste meal inclusion at $10 \%$ reflected an increase in total gain compared with control group and the other levels of DWM with no significant differences $(\mathrm{p}>0.05)$. This result confirms those obtained by Hussein et al. (1998) who found that the use of dates and date pits in broiler starter and finisher diets improved the body weight, total body weight gain, and feed utilization efficiency in chicks. Regarding total weight gain, there was no significant difference between male and female. Also, all levels of DWM with adding enzyme showed insignificant ( $>0.05)$ increase in total weight gain compared with groups without enzyme supplementation. These results are not consistant with those obtained by Choct et al. (1996) who reported that the various effects of enzyme supplementation in the digestive process are usually reflected by a considerable improvement of growth and feed conversion rates of poultry. Al-Homidan (2003) reported that adding date to broiler diets tend to increase weight gain. Also, Al-Harthi (2006) found that date waste meal can be used up to $21 \%$ in the diets of broilers. Another study by Al-Mafragy (1999) also proved that Al-Zahdi date addition leads to high increase in weight gain. They found that date waste can be fed to broilers up to $20 \%$ in the growingfinishing period during 21-40 days of age without negative effects on growth performance.

The enhancement in BWG due to enzymes mixture supplementation was reported by Tawfeek (1996) on growing rabbits and Gracia et al (2005) on broilers and recently by El-Sheikh et al (2015) on ducks. The positive effect of enzyme supplementation could be explained on the basis that enzymes mixture has specific enzymes such as xylanase, cellulase and B-glucanase. These multi-enzymes could exert a partial hydrolysis of some anti-nutritional factors in DWM (pentosans and cellulose) and hence, increase the availability of nutrients causing an improvement in live body weight (Lazaro et al., 2004).

\section{Total feed intake (TFI), feed conversion ratio (FCR) and performance index (PI)}

Data illustrated in Table (7) showed that DWM inclusion at 10\%, 20\% and 30\% reflected an insignificant increase ( $p>0.05)$ in total feed intake compared with control group. DWM inclusion at $40 \%$ reflected a significant decrease $(\mathrm{p}<0.05)$ in total feed intake compared with $10 \%, 20 \%$ and $30 \%$ while, it reflected an insignificant decrease $(\mathrm{p}>0.05)$ compared with control group. These results are in agreement with those detected by Al-Bowait and Al-Sultan (2007) and Al-Shami and Mohammed (2009) who showed that date pits inclusion in broiler diets increased feed intake when compared with control group.

There was no significant $(\mathrm{p}<0.05)$ difference in total feed intake as affected by male and female during the experimental period. Also, groups fed diets with enzyme supplementation showed insignificant 
$(\mathrm{P}<0.05)$ increase in total feed intake during the experimental period compared with those fed diets without enzyme supplementation.

The results of Table (7) cleared that, DWM inclusion at $10 \%$ achieved insignificant difference among feed conversion compared with control group, $20 \%$ and $40 \%$ (6.76 vs 7.48, 8.40 and 8.11). A significant difference $(\mathrm{p}<0.05)$ was detected with rabbits group fed dietary $30 \%$ compared to control group $(10.72 \mathrm{vs}$ 7.48). These results are in agreement with those obtained by Al-Bowait and Al-Sultan (2007) and AlShami and Mohammed (2009) who found that date pits inclusion in broiler diet increased feed intake when compared with control group.

Also, results in Table (7) showed insignificant difference among feed conversion (FC) between males and females during experimental period. It was observed that enzyme supplementation achieved insignificant $(\mathrm{p}<0.05)$ improvements in total FCR compared with those without enzyme supplementation (Table 7).

Data of performance index values presented in Table (7) showed that DWM inclusion at $10 \%$ were reflected an increase $(\mathrm{p}<0.05)$ in performance index compared with control and other experimental groups $(20,30 \%$ and $40 \%)$, but with insignificant difference $(\mathrm{p}<0.05)$ between $10 \%$, control group and $20 \%$ .While, there was a significant difference $(\mathrm{p}<0.05)$ between $10 \%$ versus $30 \%$ and $40 \%$ of date waste meal (DWM).

The same table showed that control group reflected an insignificant increase $(\mathrm{p}<0.05)$ in PI compared with $20 \%, 30 \%$ and $40 \%$ of date waste meal (DWM). These results are consistent with AL-Shami and Mohammed (2009) who stated that rejected date addition (15, 30 or 45\%) deteriorated PI when compared with the control.

Also, there was no significant difference $(\mathrm{p}<0.05)$ in PI between male and female (Table 7). The same table showed that with adding enzyme reflected a non significant increase in PI $(\mathrm{p}<0.05)$ compared with that without adding enzyme.

\section{Blood plasma parameters}

Data in Table (8) showed that total protein (TP) and Globulin (G) concentrations of plasma increased, while Albumin and Albumin/Globulin ratio $(\mathrm{A} / \mathrm{G})$ decreased $(\mathrm{P}<0.05)$ in rabbits fed 30 and $40 \%$ level of DWM inclusion in their diets in relative to rabbits fed the other levels (10 and $20 \%)$ and control group. This result is in agreement with Mohammed (2013) who stated that, there were significant $(\mathrm{P}<0.05)$ effects of date palm in the diet on serum total protein, albumin and globulin that may be due to the improvement in nutrient utilization especially protein and sugars of dates which are easily digested and absorbed. The values of the present study were in the range of normal values defined for these parameters by previous studies (Özkan et al., 2012) in rabbits.

The results of Table (8) showed no significant differences of including different levels of DWM in the diets on cholesterol, triglycerides, ALT and AST. These results are in agreement with Abdel-Fattah et al. (2012) who found that inclusion of crushed date palm (CDP) in concentrate feed mixture (CFM) at $50 \%$ (weight/weight) did not affect the activities of plasma ALT and AST and subsequently on liver function of growing Barki lambs.

The average values of blood plasma parameters concentrations for rabbits fed diets with adding zylam were nearly similar with the average values of rabbits fed diets without adding zylam (Table 8).

Regarding the effect of sex, the results obtained (Table 8) indicated that there was no significant difference between male and female for all blood plasma parameters. This result is in agreement with Abdel-Azeem et al. (2007) who found that sex had no significant effects on plasma total protein (TP), albumin $(\mathrm{A})$, globulin concentration $(\mathrm{G})$, albumin/globulin ratio $(\mathrm{A} / \mathrm{G})$ and triglycerides.

These results of blood plasma parameters indicated that inclusion different levels of DWN in the rations of rabbits were not negatively affected liver activity or rabbit's health.

\section{Mortality rate}

There were no death losses during the whole experimental period niether for the rabbit fed on control rations as the major source of fiber nor did the groups received different levels of dietary DWM. This may be an indication that growing rabbits can utilize different dietary levels of DWM.

\section{Economical efficiency}

The economical importance of poultry feeding becomes apparent, because it is well-established that feed, as a main input in poultry industry, represent about $60 \%$ to $75 \%$ of the total cost (Oladeebo and 
Abo-Eid et al.

Tables 8-9 
Ambe-Lamidi, 2007). Data of economical efficiency (EE) and relative economical efficiency (REE) estimated for the different treatments during experiment are shown in Table (9). According to the inputoutput, economical efficiency and relative economical efficiency ranged between 0.07 to 0.76 and 31.82 to $345.46 \%$, respectively for the control and the experimental treatments. The best value for EE and REE had been recorded by rabbits group fed diet contained 10\% DWM and supplemented with $1 \mathrm{~g}$ zylam (T1Z) ( (0.76 and 345.46\%) compared to the control without enzyme supplementation or control (CC) $(0.22$ and $100 \%)$. Also, data cleared that groups fed $40 \%$ DWM with enzyme supplementation recorded better values for EE and REE ( 0.37 and $168.18 \%$ vs. 0.15 and $68.18 \%$ ) than those fed the same dietary levels without enzyme supplementation. This could be due to the good role of zylam toward the high fiber fractions content of DWM. With respect to relative economical efficiency, the best value $(345.46 \%)$ had been recorded by rabbits group fed diet contained $10 \%$ DWM with enzyme supplementation.

These improvements of the EE and REE values may be due to low price of DWM and the highest weight gain of growing rabbits. These results are agree with those obtained by El-Sheikh et al (2013) who found that hens fed $40 \%$ DWM recorded the best economical efficiency and relative economical efficiency. Also, El-Sheikh et al. (2015) revealed that improvement of the EE and REE values may be due to low price of DWM and the highest weight gain of duckling. On the other hand, Masoudi et al. (2011) reported that use of date pits reduces the cost of diets but had no significant effect on meat cost. Thus, date pits may be used in poultry rations in replacement of maize, but there are no profits unless when access to corn is limited. It could be concluded that the tested diets can be used for growing rabbits without adverse effect, except diets T3Z (30\% DWN + enzyme) and T4C (40\% DWM without enzyme) which recorded $31.82 \%$ and $68.18 \%$ REE, respectively.

\section{CONCLUSION}

In general, based on the obtained results reported in this study, DWM can be incorporated in rabbit diets up to $20 \%$ with adding zylam $(0.1 \%)$ to achieve improvement in live body weight. These results are indicators to the possibility of using date palm wastes without adverse effect on growth performance, digestibility coefficients, blood serum parameters and economical efficiency in rabbits feeding at the desert areas and the new-reclaimed lands.

\section{REFERENCES}

Abdel-Azeem A. S., A. M. Abdel-Azim, A. A. Darwish and E. M. Omar (2007). Hematology and biochemistry of pure and crossed rabbits. The 5th Inter.Con.on Rabbit Prod. in Hot Clim., Hurghada, Egypt, 391-401.

Abdel-Fattah, M.S., Afaf A. Abdel-Hamid, Ashgan M. Ellamie, M.M. El-Sherief and M.S. Zedan (2012). Growth rate, some plasma biochemical and amino acid concentrations of Barki lambs fed ground date palm at Siwa Oasis, Egypt. American-Eurasian J. Agric. \& Environ. Sci., 12 (9): 1166-1175.

Al-Bowait, M. and S. Al-Sultan (2007). The effect of partial replacement of maize by alkali-treated date pits on broiler growth, survival rate and economic returns. Livestock Research and Rural development, 19:950-962.

Al-Harthi, M. A., A. A. El-Deek, H.M. Yakout, and M. AL-Refaee (2009). The nutritive value of date waste meal as a feedstuff for Lohmann Brown pullets and layers. J. Poult. Sci. 46, 303-312.

Al-Harthi, M.A. (2006). The influence of date waste meal supplemented with enzymes, probiotics or their combination on broiler performance. Egypt. Poult. Sci., 26: 1031-1055.

Al-Homidan, A. H. (2003). Date waste (whole dates and date pits) as ingredients in broiler diets. Egyptian Poultry Science, Vol. 23 (1): 15-35.

Ali, B.H., Bashir, A.K. and Alhadrami, G.A. (1999). Reproductive hormonal status of rats treated with date pits. Food Chemistry, 66: 437-441. 
Al-Mafragy, A. Y. (1999). The use of dibs in rearing broiler and its effects on some physiological and production parameters. MSc thesis. College of Veterinary Medicine. Baghdad University, (Physiology).

Al-Shami, S.A. and T.A. Mohammed (2009). Effect of replacement of barley grains by wasted bread crumbs or rejected dates on growth performance and carcass traits of growing rabbits. Pakistan Journal of Nutrition 8 (5): 635-641.

AOAC. (2000). Official methods of Analysis. $13^{\text {th }}$ Ed. Association of Official Agricultural Chemists, Washington, D.C., U.S.A.

Babatundse, G.M., B. L. Fetuga, O. Odumosu, and V. A. Oyenuga (1975). Palm kernel meal as the major protein concentrate in the diets of pigs in the tropics Journal of the Science of Food and Agriculture 26:1279-1291.

Cannon, D.C., I. Olittky and J.A. Inkpen (1974). Clinical chemistry. (Eds. Henry, R.J., Cannon, D.C., and Winkelman, J.W.). 2nd Ed., Harper \& Row. Publisher, Hagerstown, MD, USA.

Cheeke, P. R., N.M. Patton and G.S. Tempelton (1982). Rabbit production.5th Edition, Interstate Printers and Publishers Danville II., USA.

Choct M, R.J. Hughes, J, Wang, M. R. Bedford, A.J. Morgan and G. Annison (1996). Increased small intestine fermentation is partly responsible for the anti-nutritive activity on non starch polysaccharides in chickens. British Poultry Science, 37: 609-621.

Daumas B.T.( 1971). Determination of total protein and albumin in serum. Clin. Chem. Acta 31: 87-96.

Duncan, D.B., (1955). Multiple Range and Multiple F- test. Biometrics, 11:1- 42.

El-Deek A. A., M. Al-Harthi and H. M. Yakout (2008). Use of enzymes to supplement diets containing date waste meal for Lohmann White layers. International Journal of Poultry Science Vol. 7(4):397407.

El-Deek, A. A., Y. A. Attia and A. Amal Soliman (2003). Productive response of broiler breeder hens when fed practical or vegetable diets containing high levels of barley, sunflower meal or barley and sunflower meal without or with enzyme mixture supplementation. 3-barley and un-dehulled sunflower meal, Mansoura Univ. J. Agric. Sci., 28: 2525-2537.

El-Sheikh, S. E. M., N. A. Al-Shokiry, A. A. Salama and R.E. Khidr (2013). Utilization of Azzawi date meal in local laying hen diets. Egypt. Poult. Sci. Vol (33), IV: 1115-1127.

El-Sheikh, S.E.M., Mona M. H., A.A. Salama and M. El-Saeed (2015). Effect of Using Date Waste Meal asa Desert Product in Ducks Feeding. J. Advances in Environmental Biology, 9(22) Special, PP: 155-163

Fadare A.O. (2015). Feed utilization of New Zealand white, Californian, Palomino brown and Havana black rabbit in the humid tropics. Sky Journal of Agricultural Research Vol. 4(2):38-41.

FAO (2007). Food and Agriculture organization of the United Nations. Statistical data bases. Production yearbook. Top Ten dates producers-2007.

Feed Composition Tables for Animal and Poultry Feedstuffs Used In Egypt (2001). Technical bulletin. No.1, Central Lab for Feed and Food, Ministry of Agriculture, Egypt.

García, A.I., J. García, E. Corrent, S. Chamorro, P. García-Rebollar, J.C. De Blas and R. Carabaño (2005). Effect of rabbit age, type of protein and feed enzyme addition on the apparent dry matter and crude protein digestibility of rabbit feed. In: Proc. 11émes Journées de la Recherche Cunicole, 2005 November, Paris, France, 197-200.

Hussein, A. S., G. A. Alhadrami and Y.A. Khalil, (1998). The use of dates and date pits in broiler starter and finisher diets. Bioresource Technology, 66 (3) 219 -223.

Ibrahim, M. R., H. M. El-Banna, and M. A. El-Manylawi (2010). Evaluating utilization of ground date stone meal with or without kemzyme in the diets of growing New Zealand rabbits. IV International Date Palm Conference,15-17 March, 2010, Abu Dubi, UAE. Acta Hort. (ISHS) 882:691-697.

Jassim S. A. and M. A. Naji (2010). In vitro Evaluation of the Antiviral Activity of an Extract of Date Palm (Phoenix dactylifera L.) Pits on a Pseudomonas Phage. Evid Based Complement Alternat Med., 7: 57-62. 
Jiao S, C. Maltecca, K. A. Gray and J. P. Cassady (2014). Feed intake, average daily gain, feed efficiency, and real-time ultrasound traits in Duroc pigs: I. Genetic parameters estimation and accuracy of genomic prediction. J. Anim. Sci. 92: 2377-2386.

Lazaro, R., M.A. Latorre, P. Medel, M. Gracia and G.G. Mateos (2004). Feeding regimen and enzyme supplementation to rye-based diets for broilers. Poult. Sci., 83: 152-160.

Messaoudi, M., R. Lalonde, N. Violle, H. Javelot, D. Desor, A. Nejdi, Jean F.O. Bisson, C. Rougeot, M. Pichelin, M. Cazaubiel and J. M. Cazaubiel (2011). Assessment of psychotropic-like properties of a probiotic formulation (Lactobacillus helveticus R0052 and Bifidobacterium longum R0175) in rats and human subjects, British Journal of Nutrition, 105: 755-764.

Mohammed, M.F. (2013). The influence of adding date to broiler diet on performance and blood characters. International Journal of Advanced Biological Research, Vol. 3(4) 2013: 540-544.

Najib, H.A., Y.M. Al-Yousef and M. Hmeidan (1995). Use of dates as energy sources in the layer ration. J. Appl. Anim. Res., 6: 91-96.

North, M.O. (1981). Comercial Chicken Production Manual, 2 Edation . AVI .

NRC, (1994). Nutrient Requirements of Poultry. $9^{\text {th }}$ rev. ed. Nat 1. Acad. Press. Washington.

Ogunsipe, M. H. (2014). Effect of poultry litter with or without enzyme supplementation on the growth performance, nutrient digestibility and economy of rabbit production. International Journal of Livestock Production, Vol 5(2):23-29.

Oladeebo, J.O. and A.I. Ambe- Lamidi (2007). Profitability, Input Elasticities and Economic Efficiency of Poultry Production among Youth Farmers in Osun State, Nigeria. International Journal of Poultry Science 6 (12): 994-998.

Özkan C., A. Kaya and Y. Akgül (2012). Normal values of haematological and some biochemical parameters in serum and urine of New Zealand white rabbits. World Rabbit Sci., 20: 253 - 259.

Reitman, S. and Frankel, S. (1957) A colorimetric method for the determination of serum glutamic oxaloacetic and glutamic pyruvic transaminases. Am. J. Clin. Path., 28: 56.

SAS (2006). Statistical Analysis System, User's Guide, Statistics, SAS Institute Carry, North Carolina.

Sawaya, W. N., J. K. Khalid and W. J. Safi (1984). Chemical composition and nutritional quality of date seeds. Journal Food Science, 49: 617-619.

Taha, H.J., F.M. Al-Yasri, M.H. Mayada and F. Alkhilani (2013). Effect of addition different levels of dates flesh (Phoenix dactyliphera $L$ ) to ration contain probiotic on boiler chickens performance reared under heat stress. I.J.A.B.R, Vol. 3 (2) 2013: 306-31.

Tawfeek, M. I., (1996). Effect of feeding system and supplemented diet with Alltech ${ }^{\circledR}$ enzyme on growth, blood constituents, carcass traits and reproductive performance in rabbits under intensive production conditions. Egyptian Journal of Rabbit Science, 6: 21 - 37.

Trinder, P. (1969). Estimation of triglycerides in blood GPO-PAP enzymatic method. American Clin. Biochem., 6: 24-7.

Watson, D. (1960). Determination of cholesterol in blood serum. Clin.Chem.Acta, 5:637. 


\title{
تأثير إضافة مستويات مختلفة من مخلف البلح على آداء الأرانب النامية
}

\author{
حسنى السيد أحمد حسن أبوعيد1 ، محمود سعد أبو سكين1 ، إبراهيم الفولى² \\ 1- قسم التنمية المتو اصلة للبيئة ـ معهل الدراسات و البحوث البيئية - جامعة هدينة السادات ـ محافظة المنوفية ـ مصر البرد \\ 2- 2 - مركز بحوث الصحر اء - وزارة الزراعة - مصر .
}

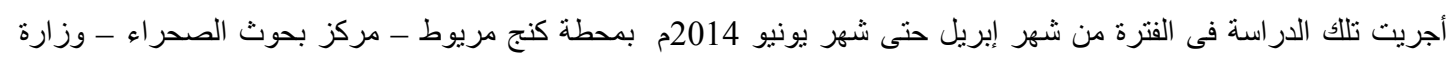

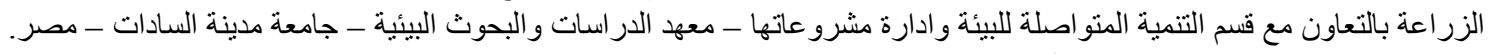

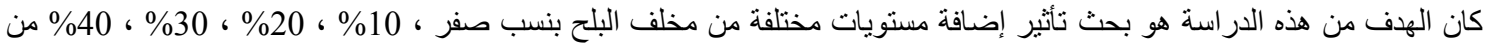

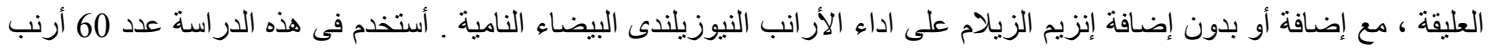

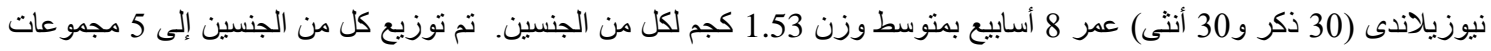

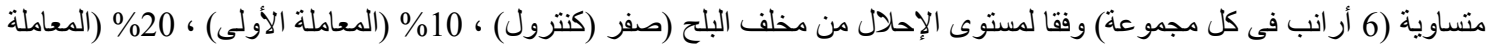

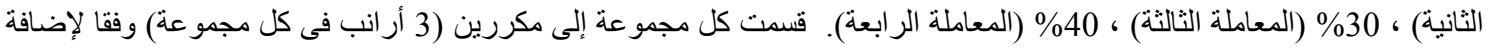

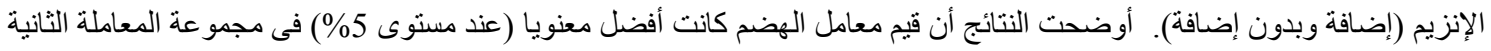

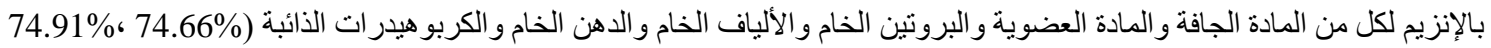

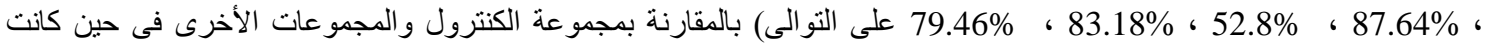

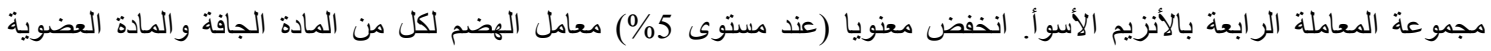

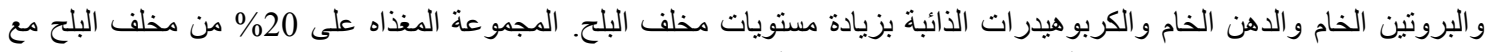

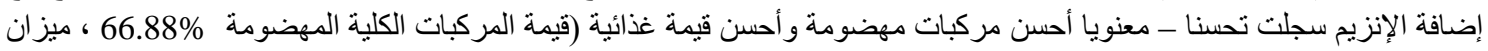

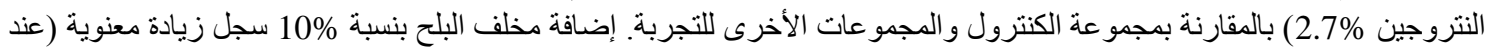

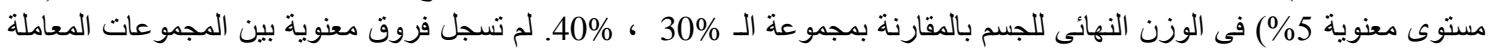

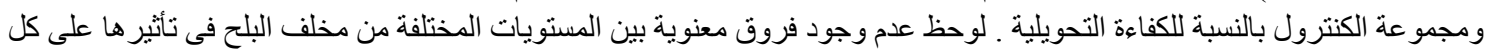

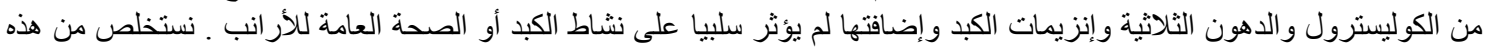

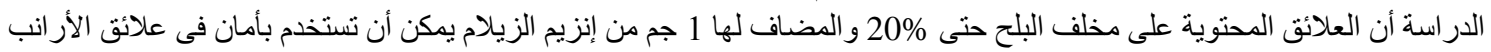

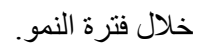

